\title{
ANALISIS TINGKAT KESEHATAN BMT NURUL ISLAM BATAM BERDASARKAN PERMENKOP NOMOR: 35.3/PER/M.KUKM/X/2007 TAHUN 2017-2019
}

\author{
Abdul Wachid; Fitri Miswati \\ Institut Agama Islam Abdullah Said Batam, Kepulauan Riau \\ Email : muhammadshalih061216@gmail.com; miswatifitri815@gmail.com
}

\begin{abstract}
Abstrak
Penelitian ini bertujuan untuk mengetahui bagaimana tingkat kesehatan Lembaga Keuangan Mikro Syariah secara khusus untuk BMT Nurul Islam Batam sebagai objek penelitian. Analisis tingkat kesehatan BMT Nurul Islam Batam dengan menggunakan pedoman yang telah dikeluarkan oleh Kementrian Koperasi Nomor: 35.3/Per/M.KUKM/X/2007 tentang pedoman kesehatan KJKS dan UJKS. Aspek yang di nillai dalam pedoman tersebut ada delapan yaitu aspek permodalan, kualitas aktiva produktif, manajemen, efisiensi, likuiditas, kemandirian dan pertumbuhan, jati diri koperasi dan kepatuhan prinsip syariah. Periode yang digunakan pada penelitian ini yaitu tahun 2017-2019 Hasil penelitian tingkat kesehatan yang dilakukan pada BMT Nurul Islam Batam periode 2017-2019 dari aspek permodalan, kualitas aktiva produktif, efisiensi dan likuiditas berdasarkan peraturan menteri koperasi No 35.3/Per/M.KUKM/X/2007 mendapatkan predikat sehat.
\end{abstract}

Key words: kesehatan lembaga keuangan; LKMS; KJKS; UJKS

PENDAHUAN

Perubahan Baitul Mal wa Tamwil merupakan bentuk dari Koperasi Jasa keuangan syariah (KJKS) yang merupakan bagian dari Lembaga Keuangan Jasa Syariah (LJKS). Belakangan ini berdasarkan laporan dari OJK (Otoritas Jasa Keuangan) pada awal 2020 tercatat sebanyak 75 koperasi syariah yang sebelumnya pada awal tahun 2018 hanya sebesar 38 koperasi syariah. Koperasi syariah tersebut lebih banyak muncul dalam bentuk BMT. Pesatnya pertumbuhan BMT dalam kurun waktu tak lebih dari 3 tahun terakhir tersebut tentu menjadi bahan bagi BMTBMT untuk semakin memperbaiki kinerja untuk dpat menjaga keberlangsungannya. Pada akhirnya BMT yang sehat saja yang mampu eksis ditengah perubahan yang begitu cepat ini.
Tingkat kesehatan BMT selanjutnya akan berpengaruh terhadap kemampuan BMT Nurul Islam sebagai BMT perintis yang sejak tahun 2012 mulai menjalankan kiprahnya untuk mengembangkan kegiatan usahanya, sehingga penilaian kesehatan ini harus dilakukan oleh BMT Nurul Islam untuk mengukur sejauh mana BMT Nurul Islam mampu memaksimalkan kegiatan usahanya. Penilaiaan tingkat kesehatan BMT sudah diatur dalam Permenkop No: 35.3/Per/M.KUKM/X/2007 tentang penilaian pedoman kesehatan KJKS dan UJKS

Terbitnya pedoman penilaian tingkat kesehatan KJKS dan UJKS melalui Permenkop No. 35.3/Per/M.KUKM/X/2007 tersebut seharusnya bisa menjadi rujukan bagi BMT dalam melakukan penilaian tingkat kesehatannya, namun ternyata pedoman 
ini tidak selamanya menjadi rujukan oleh BMT dalam melakukan penilaiannya. Sehingga perlu di teliti lebih lanjut bagaimana implementasi penilaian tingkat kesehatan BMT Nurul Islam berdasarkan Permenkop No: 35.3/Per/M.KUKM/X/2007.

\section{METODE}

Berdasarkan pedoman penilaian tingkat kesehatan KJKS dan UJKS yang di keluarkan menteri koperasi No. 35.3/Per/M.KUKM/X/2007 maka akan dianalisa 8 aspek yang meliputi: permodalan, kualitas aktiva produktif, manajemen, efisiensi, likuiditas, kemandirian, jatidiri koperasi serta kepatuhan prinsip syariah. Namun karena keterbatasan peneliti, maka hanya 4 aspek yang menjadi fokus analisa yaitu: permodalan, kualitas aktiva produktif, efisiensi dan likuiditas yang kesemuanya dilakukan dengan pendekatan kuantitatif.

\section{HASIL DAN PEMBAHASAN Lembaga Keuangan Mikro Syariah}

Menurut undang-undang No. 1 tahun 2013 tentang lembaga keuangan mikro, lembaga keuangan mikro syariah adalah lembaga keuangan mikro yang menggunakan prinsip-prinsip syariah dengan adanya Dewan Pengawas Syariah guna mengawasi operasional yang sesuai dengan fatwa Dewan Syariah Nasional.

Menurut Krishnamurti (2005), walaupun terdapat banyak definisi tentang lembaga keuangan mikro, namun secara umum terdapat 3 elemen penting dari berbagai definisi tersebut. Pertama, menyediakan beragam jenis pelayanan keuangan. Keuangan mikro dalam pengalaman masyarakat tradisional Indonesia seperti lumbung desa, lumbung pitih nagari dan sebagainya menyediakan layanan keuangan yang beragam, seperti tabungan, pinjaman, pembayaran,

\section{JQIM}

deposito maupun asuransi. Kedua, melayani masyarakat miskin. Keuangan mikro pada awalnya hidup dan berkembang memang untuk rakyat yang terpinggirkan oleh sistem keuangan formal yang ada sehingga memiliki karakteristik konstituen yang khas. Ketiga, menggunakan prosedur dan mekanisme yang konstektual dan fleksibel. Hal ini merupakan konsekuensi dari kelompok masyarakat yang dilayani, sehingga prosedur dan mekanisme yang dikembangkan untuk keuangan mikro akan senantiasa kontekstual dan fleksibel.

Di Indonesia ada 3 tipe LKMS yaitu, Baitul Maal wat Tamwil (BMT) atau disebut juga dengan koperasi syariah, sistem grameen yang diadopsi dari sistem Grameen Bank yang dipelopori oleh mahmud yunus dari Bangladesh) dan sistem campuran (koperasi syariah sekaligus grameen).

\section{Baitul Maal Wa Tamwil}

Pinbuk (1995) menyatakan bahwa

Baitul Maal Wa Tamwil (BMT) merupakan lembaga ekonomi rakyat kecil yang berupaya mengembangkan usahausaha produktif dan investasi dalam meningkatkan kegiatan ekonomi pengusaha kecil dan berdasarkan prinsip syariah. Fungsi BMT dapat digmbarkan dengan skema berikut.

\section{Tingkat Kesehatan BMT Nurul Islam}

Lembaga Keuangan Mikro Syariah dalam hal ini BMT melaksanakan kegiatan operasinalnya sama halnya dengan lembaga perbankan dimana sebagai lembaga intermediasi anatara pihak yang membutuhkan dana dan pihak yang kelebihan dana. Kesehatan BMT merupakan hal yang sangat penting karena BMT yang sehat mencerminkan bahwa keadaan BMT sudah sebagaimana mestinya, dapat 
menajalankan fungsi-fungsinya dengan baik, terpelihaa kepercayaan masyarakat, dapat membantu kelancaran lalu lintas pembayaran, terpeliharanya likuiditas sehingga dapat memenuhi kewajibannya setiap saat.

Penilaian tingkat kesehatan BMT bisa dilakukan dengan beberapa metode salah satunya yaitu dengan Permenkop No. 35.3/Per/M.KUKM/X/2007 tentang pedoman penilaian tingakt kesehatan KJKS dan UJKS sebagai kriteria dalam menilai tingkat kesehatan BMT. Dalam Permenkop tersebut ada delapan aspek yang dinilai yaitu Permodalan, Kualitas Aktiva Produktif, Manajemen, Efisiensi, Likuiditas, Kemandirian dan pertumbuhan, Jati diri koperasi, dan Prinsip Syariah

BMT Nurul Islam sebagai salah satu Lembaga Keuangan Mikro Syariah yang berbadan hukum koperasi untuk bisa tetap eksis menjalankan usahanya tentu sudah semestinya melaksanakan penilaian kesehatan pada setiap periode. Penilaian tingkat kesehatan BMT Nurul Islam juga dilakukan agar BMT Nurul Islam dapat melakukan evaluasi serta untuk mengetahui beberapa masalah dalam kegiatan usahanya.

Analisis kesehatan BMT yang dilakukan dalam penelitian ini yaitu analisa permodalan, kualitas aktiva efisiensi dan likuiditas dengan menggunakan pendekatan analisis kuantitatif. adapun penilaian dari ke empat aspek diatas dilakukan dengan menggunakan standar sebagai berikut:

1. Permodalan

Penilaian yang dilakukan dalam aspek permodalan ini menggunakan dua rasio permodalan yaitu perbandingan modal sendiri dengan total aset dan rasio kecukupan modal (CAR). Rasio modal

\section{JQIM}

sendiri dengan total aset ini di anggap sehat apabila nilainya maksimal $20 \%$. Sedangkan rasio kecukupan modal atau capital adequacy ratio (CAR) akan dikatakan sehat apabila nilai CAR mencapai $8 \%$ atau lebih, semakin tinggi nilai dari $8 \%$ menunjukan KJKS/UJKS koperasi semakin sehat

Untuk memperoleh rasio modal sendiri terhadap total modal ditetapkan sebagai berikut:

a. Untuk rasio permodalan lebih kecil atau sama dengan 0 diberikan nilai kredit 0

b. Untuk setiap kenaikan rasio permodalan $1 \%$ mualai dari 0 nilai ditambah 5 dengan maksimum nilai 100

c. Nilai kredit dikalikan bobot sebesar $5 \%$ diperolehlah skor permodalan

Tabel. 2

Penetapan Kriteria Rasio Modal Sendiri Terhadap Total Modal

\begin{tabular}{ccccc}
\hline Rasio Kas (\%) & $\begin{array}{c}\text { Nilai } \\
\text { Kredit }\end{array}$ & $\begin{array}{c}\text { Bobot } \\
(\%)\end{array}$ & Skor & Kriteria \\
\hline 0 & 0 & 5 & 0 & $0-1,25$ Tidak Sehat \\
5 & 25 & 5 & 1,25 & $1,26-2,5$ Kurang Sehat \\
10 & 50 & 5 & 2,5 & $2,51-3,75$ Cukup Sehat \\
15 & 75 & 5 & 3,75 & $3,76-5$ Sehat \\
20 & 100 & 5 & 5 & \\
\hline
\end{tabular}

Perhitungan rasio CAR ditetapkan dengan tahapan sebagai berikut:

a. Menghitung nilai modal sendiri (modal inti) dan modal pelengkap yang karakteristiknya sama dengan modal sendiri dengan cara menjumlahkan hasil perkalian setiap komponen modal KJKS/UJKS Koperasi yang ada dalam neraca dengan bobot pengakuannya.

b. Menghitung niali ATMR diperoleh dengan cara menjumlahkan hasil perkalian nilai nominal aktiva yang ada dalam neraca dengan bobot risiko masing-masing komponen aktiva

c. Rasio CAR dihitung dengan cara membandingkan nilai modal yang diakui dengan nilai ATMR dikalikan dengan $100 \%$ maka diperoleh rasio CAR 
d. Untuk rasio CAR lebih kecil dari $6 \%$ diberi nilai kredit 25 , untuk kenaikan rasio CAR $1 \%$ niali kredit ditambah dengan 25 sampai dengan nilai CAR $8 \%$ nilai kredit maksimal 100

e. Nilai kredit dikalikan dengan bobot $5 \%$, diperoleh skor CAR

Tabel. 3

Penetapan Kriteria Rasio CAR

\begin{tabular}{ccccc}
\hline Rasio CAR (\%) & $\begin{array}{c}\text { Nilai } \\
\text { Kredit }\end{array}$ & $\begin{array}{c}\text { Bobot } \\
(\%)\end{array}$ & Skor & Kriteria \\
\hline$<6$ & 25 & 5 & 1,25 & Tidak Sehat \\
$6-<7$ & 50 & 5 & 2,5 & Kurang Sehat \\
$7-<8$ & 75 & 5 & 3,75 & Cukup Sehat \\
$>=8$ & 100 & 5 & 4 & Sehat \\
\hline
\end{tabular}

2. Kualitas Aktiva Produktif

Penilaian terhadap kualitas aktiva produktif didasarkan pada 3 (tiga) rasio, yaitu Rasio tingkat piutang dan pembiayaan bermasalah terhadap jumlah piutang dan pembiayaan, Rasio Portofolio terhadap piutang beresiko dan pembiayaan beresiko PAR (Portofolio Asset Risk), dan Rasio Penyisihan dan Penghapusan Aktifa Produktif (PPAP) terhadap Penyisihan Penghapusan Aktiva Produktif Yang Wajib Dibentuk (PPAPWD).

Untuk memperoleh rasio piutang dan pembiayaan bermasalah terhadap piutang dan pembiayaan yang disalurkan, ditetapkan sebagai berikut:

a. Untuk rasio lebih besar dari $12 \%$ sampai dengan $100 \%$ diberi nilai skor 25

b. Untuk setiap penurunan rasio 3\% nilai kredit ditambah dengan 5 sampai maksimum 100.

Nilai kredit dikalikan bobot $10 \%$ diperoleh skor penilaian sebagai berikut:

Tabel. 4

Penetapan Kriteria Rasio Piutang dan

Pembiayaan Bermasalah

Terhadap Piutang dan Pembiayaan yang Disalurkan

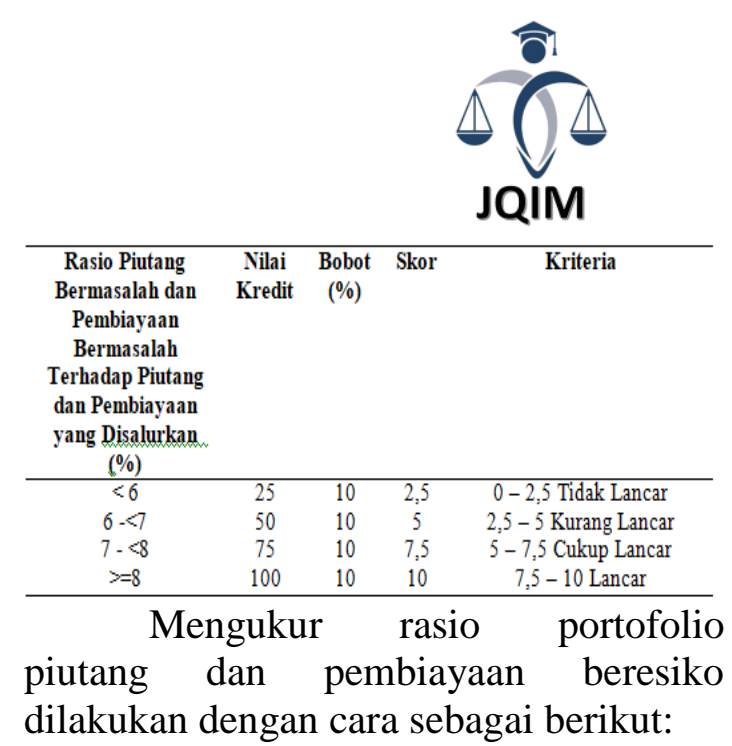

a. Mengklasifikasikan tingkat keterlambatan ke dalam kelompok

1) Lambat 1 - 30 hari (portofolio beresiko 1)

2) Lambat 31 - 60 hari (portofolio beresiko 2)

3) Lambat 61 - 90 hari (portofolio beresiko 3)

4) Lambat > 90 hari (portofolio beresiko 4)

b. Membandingkan piutang dan pembiayaan bermasalah pada periode tersebut dengan total piutang dan pembiayaan dengan cara:

1) Keterlambatan 1 - 30 hari

2) Keterlambatan $31-60$ hari

3) Keterlambatan 61 - 90 hari

4) Keterlambatan lebih dari 90 hari

c. Menghitung rasio total portofolio piutang dan pembiayaan beresiko dilakukan dengan cara sebagai berikut: Total PAR (Total Portofolio piutang dan pembiayaan beresiko) $=$

$(1)+(2)+(3)+(4)=\ldots \ldots \ldots . . \%$

d. Cara menentukan skor

1) Untuk rasio lebih besar dari $30 \%$ sampai dengan $100 \%$ diberi nilai kredit 25, untuk setiap penurunan rasio $1 \%$ nilai kredit ditambah dengan 5 sampai dengan maksimum 100 .

2) Nilai kredit dikalikan bobot $5 \%$ diperoleh skor penilaiaan

Tabel. 5

Penetapan Kriteria Rasio Portofolio

Piutang dan Pembiayaan Beresiko 


\section{JQIM}

\begin{tabular}{ccccc}
\hline Rasio PAR (\%) & $\begin{array}{c}\text { Nilai } \\
\text { Kredit }\end{array}$ & $\begin{array}{c}\text { Bobot } \\
(\%)\end{array}$ & Skor & Kriteria \\
\hline$>30$ & 25 & 5 & 1,25 & Sangat Beresiko \\
$26-30$ & 50 & 5 & 2,5 & Kurang Beresiko \\
$21-26$ & 75 & 5 & 3,75 & Cukup Beresiko \\
21 & 100 & 5 & 4 & Tidak Beresiko \\
\hline
\end{tabular}

Rasio Penyisihan Penghapusan

Aktiva Produktif (PPAP) terhadap penyisihan aktiva produktif yang wajib dibentuk (PPAPWD). Rasio ini menunjukan kemampuan KJKS/UJKS koperasi dalam menyisihkan pendapatannya untuk menutupi risiko (penghapusan) aktiva produktif yang disalurkan dalam bentuk pembiayaan dan piutang. Pengukuran tingkat kesehatan rasio ini ditetapkan sebagai berikut:

a. Mengklasifikasikan aktiva produktif berdasarkan kolektibilitasnya, yaitu:
1) Lancar
2) Kurang lancar
3) Diragukan
4) Macet

b. Menghitung nilai PPAP dari neraca pada komponen cadangan penghapusan pembiayaan

c. Menghitung PPAPWD dengan cara mengalihkan komponen presentase pembentukan PPAPWD dengan kolektibilitas aktiva produktif. Perhitungan PPAPWD

1) $0,5 \%$ dari aktiva produktif lancar

2) $10 \%$ daria ktiva produktif kurang lancar dikurangi nilai agunannya

3) $50 \%$ dari aktiva produktif diragukan dikurangi nilai agunannya.

4) $100 \%$ dari aktiva produktif macet dikurangi nilai agunannya.

d. Rasio penyisihan penghapusan aktiva produktif dapat diperoleh/dihitung dengan membandingkan nilai PPAP dengan PPAPWD dikalikan dengan $100 \%$

e. Untuk rasio PPAP sebesar $0 \%$ nilai kredit sama dengan 0 . Untuk setiap kenaikan rasio PPAP 1\% nilai kredit ditambah 1 sampai dengan maksimum 100 f. Nilai kredit dikalikan dengan bobot 5\% diperoleh skor tingkat rasio PPAP

Tabel. 6

Penetapan Kriteria Rasio PPAP dan PPAPWD

\begin{tabular}{ccccc}
\hline Rasio PPAP (\%) & $\begin{array}{c}\text { Nilai } \\
\text { Kredit }\end{array}$ & $\begin{array}{c}\text { Bobot } \\
(\%)\end{array}$ & Skor & Kriteria \\
\hline 0 & 0 & 5 & 0 & \\
10 & 10 & 10 & 0,5 & \\
20 & 20 & 5 & 1 & $0-<1,25$ Macet \\
30 & 30 & 5 & 1,5 & $1,25-<2,5$ Diragukan \\
40 & 40 & 5 & 2,0 & $2,50-<3,75$ Kurang \\
50 & 50 & 5 & 2,5 & lancar \\
60 & 60 & 5 & 3,0 & $3,75-5,0$ Lancar \\
70 & 70 & 5 & 3,5 & \\
80 & 80 & 5 & 4 & \\
90 & 90 & 5 & 4,5 & \\
100 & 100 & 5 & 5 & \\
\hline
\end{tabular}

3. Penilaiaan efisiensi

Penilaian efisinsi KJKS/UJKS koperasi didasarkan pada 3 rasio yaitu rasio biaya operasional terhadap pelayanan, rasio aktiva terhadap total aset dan rasio efisiensi staf. Cara perhitungan rasio biaya operasional atas pelayanan ditetapkan sebagai berikut:

a. Untuk rasio lebih besar dari 100 diperoleh nilai kredit 25 dan untuk setiap penurunan rasio $15 \%$ nilai kredit ditambahkan dengan 25 sampai dengan maksimum nilai kredit 100

b. Nilai kredit dikalikan dengan bobot sebesar $4 \%$ diperoleh skor penilaian Tabel.7

Penetapan Kriteria Rasio Biaya Operasional Terhadap Pelayanan

\begin{tabular}{ccccc}
\hline $\begin{array}{c}\text { Rasio Biaya } \\
\text { Operasional } \\
\text { Layanan (\%) }\end{array}$ & $\begin{array}{c}\text { Nilai } \\
\text { Kredit }\end{array}$ & $\begin{array}{c}\text { Bobot } \\
(\%)\end{array}$ & Skor & Kriteria \\
\hline$>100$ & 25 & 4 & 1 & Tidak Efisien \\
$85-100$ & 50 & 4 & 2 & Kurang Efisien \\
$69-84$ & 75 & 4 & 3 & Cukup Efisien \\
$0-68$ & 100 & 4 & 4 & Efisien \\
\hline
\end{tabular}

Rasio aktiva tetap terhadap total moadal ditetapkan sebagai berikut:

a. Untuk rasio lebih besar dari $76 \%$ diperoleh nilai kredit 25 dan untuk setiap penurunan rasio $25 \%$ niali kredit ditambahkan dengan 25 sampai dengan maksimum 100

b. Nilai kredit dikalikan dengan bobot sebesar $4 \%$ diperoleh skor penilaian:

Tabel. 8

Penetapan Kriteria Rasio Aktiva Tetap Terhadap Total Modal 


\begin{tabular}{ccccc}
\hline $\begin{array}{c}\text { Rasio Aktiva Tetap } \\
\text { Terhadap Total } \\
\text { Modal }(\%)\end{array}$ & $\begin{array}{c}\text { Nilai } \\
\text { Kredit }\end{array}$ & $\begin{array}{c}\text { Bobot } \\
(\%)\end{array}$ & Skor & Kriteria \\
\hline$>100$ & 25 & 4 & 1 & Tidak Efisien \\
$85-100$ & 50 & 4 & 2 & Kurang Efisien \\
$69-84$ & 75 & 4 & 3 & Cukup Efisien \\
$0-68$ & 100 & 4 & 4 & Efisien \\
\hline
\end{tabular}

Rasio efisiensi staff ditetapkan sebagai berikut:

a. Untuk rasio kurang dari 50 orang diberi nilai kredit 25 dan untuk setiap penurunan rasio 25 orang nilai skor ditambah dengan 25 sampai dengan maksimum nilai kredit 100

b. Nilai kredit dikalikan dengan bobot sebesar 2\% diperoleh skor penilaian:

Tabel 3.9

Penetapan Kriteria Rasio Aktiva Tetap Terhadap Total Modal

\begin{tabular}{ccccc}
\hline $\begin{array}{c}\text { Rasio Efisiensi Staff } \\
\text { (orang) }\end{array}$ & $\begin{array}{c}\text { Nilai } \\
\text { Kredit }\end{array}$ & $\begin{array}{c}\text { Bobot } \\
(\%)\end{array}$ & Skor & Kriteria \\
\hline$<50$ & 25 & 2 & 0,5 & Tidak Efisien \\
$50-74$ & 50 & 2 & 1 & Kurang Efisien \\
$75-99$ & 75 & 2 & 1,5 & Cukup Efisien \\
$>99$ & 100 & 2 & 2 & Efisien \\
\hline
\end{tabular}

\section{Likuiditas}

Penilaian kuantitatif terhadap likuiditas KJKS/UJKS koperasi dilakukan terhadap 2 (dua) rasio, yaitu rasio kas dan rasio pembiayaan. Pengukuran rasio kas terhadap dana yang diterima ditetapkan sebagai berikut:

a. Untuk rasio kas lebih kecil dari $14 \%$ dan lebih besar dari $56 \%$ diberi nilai kredit 25, untuk rasio antara $14 \%$ samapai dengan $20 \%$ dan antara $46 \%$ sampai dengan $56 \%$ diberi nilai kredit 50, rasio antara $21 \%$ sampai dengan $25 \%$ dan $35 \%$ sampai dengan $45 \%$ diberi nilai 75 , dan untuk rasio $26 \%$ sampai dengan $34 \%$ diberi nilai kredit 100.

b. Nilai kredit dikalikan dengan bobot $10 \%$ diperoleh skor penilaian

Tabel.10

Penetapan Kriteria Pengukuran Rasio Kas Terhadap Dana yang Diterima

\begin{tabular}{ccccc}
\hline Rasio Kas (\%) & $\begin{array}{c}\text { Nilai } \\
\text { Kredit }\end{array}$ & $\begin{array}{c}\text { Bobot } \\
(\%)\end{array}$ & Skor & Kriteria \\
\hline$<14$ dan $>56$ & 25 & 10 & 2,5 & Tidak Likuid \\
$(14-20)$ dan $(46-56)$ & 50 & 10 & 5 & Kurang Likuid \\
$(21-25)$ dan $(35-45)$ & 75 & 10 & 7,5 & Cukup Likuid \\
$(26-34)$ & 100 & 10 & 10 & Likuid \\
\hline
\end{tabular}

Pengukuran rasio pembiayaan terhadap dana yang diterima ditetapkan sebagai berikut:

a. Untuk rasio kas lebih kecil dari 50\% diberi nilai kredit 25 , untuk setiap kenaikan rasio $25 \%$ nilai kredit ditambah dengan 25 sampai dengan maksimum 100

b. Nilai kredit dikalikan dengan bobot $5 \%$ diperoleh skor penilaian

Tabel.11

Penetapan Kriteria Rasio Pembiayaan Terhadap Dana yang Diterima

\begin{tabular}{ccccc}
\hline $\begin{array}{c}\text { Rasio Pembiayaan } \\
\text { (\%) }\end{array}$ & $\begin{array}{c}\text { Nilai } \\
\text { Kredit }\end{array}$ & $\begin{array}{c}\text { Bobot } \\
(\%)\end{array}$ & Skor & Kriteria \\
\hline$<50$ & 25 & 5 & 1,25 & Tidak Likuid \\
$51-75$ & 50 & 5 & 2,5 & Kurang Likuid \\
$76-100$ & 75 & 5 & 3,75 & Cukup Likuid \\
$>100$ & 100 & 5 & 5 & Likuid \\
\hline
\end{tabular}

\section{Aspek Permodalan}

Tabel.12

Perhitungan Rasio Total Modal terhadap Modal Sendiri tahun 2017-2019

\begin{tabular}{clll}
\hline Tahun & Modal Sendiri & Total Modal & Rasio \\
\hline 2017 & Rp $940.628 .405,74$ & Rp 1.475.372.488,24 & $64 \%$ \\
2018 & Rp1.362.471.218,42 & Rp 1.775.358.262,21 & $77 \%$ \\
2019 & Rp1.640.898.615,30 & Rp 2.385.970.721,75 & $69 \%$ \\
\hline \multicolumn{4}{l}{ Sumber: Laporan Keuangan BMT Nurul Islam(Telah diolah) }
\end{tabular}

Tampak pada tabel bahwa rasio antara modal sendiri dengan total modal mengalami fluktuasi, namun pada setiap tahunnya rasio tersebut masih diatas standar rasio yang ditetapkan yaitu $20 \%$ sehingga BMT Nurul Islam untuk aspek ini dinyatakan SEHAT

Tabel.13

Perhitungan Rasio Kecukupan Modal CAR Tahun 2017-2019

\begin{tabular}{cllll}
\hline Tahun & Modal Tertimbang & ATMR & CAR \\
\hline 2017 & $\operatorname{Rp}$ & $340.728 .435,14$ & $\operatorname{Rp~} 4.976 .282 .428,74$ & $6,85 \%$ \\
2018 & $\operatorname{Rp} 764.271 .208,82$ & $\operatorname{Rp~} 8.975 .358 .863,20$ & $8,52 \%$ \\
2019 & Rp1. 240.178.015,32 & Rp 19.315.276.721,75 & $6,77 \%$ \\
\hline \multicolumn{5}{l}{ Sumber: Laporan Keuangan BMT Nurul Islam(Telah diolah) }
\end{tabular}


Dari hasil perhitungan rasio CAR BMT Nurul Islam dari tahun 2017 sampai tahun 2019 maka pada tahun 2018 BMT Nurul Islam untuk rasio CAR dinyatakan sehat, sementara pada tahun 2017 dan 2019 belum sehat

\section{Aspek Kualitas Aktiva Produktif}

a. Rasio Tingkat Pembiayaan Dengan Piutang Bermasalah Terhadap Jumlah Piutang Dan Pembiayaan

Tabel.14

Perhitungan Rasio Tingkat Pembiayaan dengan Piutang Bermasalah Terhadap Piutang dan Pembiayaan Tahun 20172019

\begin{tabular}{cllll}
\hline Tahun & $\begin{array}{l}\text { Jumlah Pembiayaan } \\
\text { Piutang Bermasalah }\end{array}$ & $\begin{array}{l}\text { Jumlah Piutang } \\
\text { Pembiayaan }\end{array}$ & \& Rasio \\
\hline 2017 & Rp $442.578 .435,24$ & & Rp 9.476.202.418,13 & $4,67 \%$ \\
2018 & Rp $764.471 .238,72$ & & Rp 13.905.358.863,42 & $5,50 \%$ \\
2019 & Rp $440.128 .815,22$ & Rp 10.815.276.721,91 & $4,07 \%$ \\
\hline \multicolumn{2}{l}{ Sumber: Laporan Keuangan BMT Nurul Islam(Telah diolah) }
\end{tabular}

Terlihat dari tabel diatas bahwa rasio tingkat pembiayaan bermasalah BMT Nurul Islam yang diatas $5 \%$ terjadi pada tahun 2018 artinya pada tahun tersebut rasio pembiayaan pada posisi tidak lancar, sementara pada tahun 2017 dan 2019 ada pada posisi lancar.

b. Rasio Portofolio Pembiayaan Beresiko

Tabel. 15

Perhitungan Rasio Portofolio Pembiayaan

Beresiko Tahun 2017-2019

\begin{tabular}{cllll}
\hline Tahun & $\begin{array}{l}\text { Jumlah Pembiayaan } \\
\text { Piutang Bermasalah }\end{array}$ & $\begin{array}{l}\text { Jumlah Piutang } \\
\text { Pembiayaan }\end{array}$ & Rasio \\
\hline 2017 & $\mathrm{Rp}$ & $1.242 .508 .435,43$ & $\mathrm{Rp} 9.476 .202 .418,13$ & $13,11 \%$ \\
2018 & $\mathrm{Rp}$ & $1.206 .471 .238,27$ & $\mathrm{Rp} 13.905 .358 .863,42$ & $8,68 \%$ \\
2019 & $\mathrm{Rp}$ & $1.210 .440 .128,32$ & $\mathrm{Rp} 10.815 .276 .721,91$ & $11,19 \%$ \\
\hline \multicolumn{5}{l}{ Sumber: Laporan Keuangan BMT Nurul Islam(Telah diolah) }
\end{tabular}

Terlihat pada tabel untuk aspek portofolio pembiayaan beresiko, BMT Nurul Islam dari tahun 2017-2019 memiliki nilai Rasio di bawah $21 \%$ sehingga pada aspek Portofolio pembiayaan dinyatakan Tidak Beresiko
Tabel.16

Perhitungan Rasio Penyisihan Aktiva Produktif 2017-2019

\begin{tabular}{|c|c|c|c|}
\hline Tahun & PPAP & PPAPWD & Rasio \\
\hline 2017 & $\operatorname{Rp} \quad 174.518 .235,13$ & Rp 176.702.438,42 & $98,76 \%$ \\
\hline 2018 & Rp $\quad 276.871 .248,87$ & $\operatorname{Rp} 290.358 .263,18$ & $95,36 \%$ \\
\hline 2019 & $\operatorname{Rp} \quad 310.440 .128,12$ & $\operatorname{Rp} 281.271 .021,26$ & $110,37 \%$ \\
\hline
\end{tabular}

Terlihat pada tabel bahwa Rasio penyisihan aktiva produktif BMT Nurul Islam ada yaitu di atas $80 \%$ dengan nilai 4,0 maka dapat dinyatakan bahwa penyisihan aktiva produktif BMT Nurul Islam Lancar.

\section{Aspek Efisiensi}

Penilaian efisinsi KJKS/UJKS koperasi didasarkan pada 3 rasio yaitu rasio biaya operasional terhadap pelayanan, rasio aktiva terhadap total aset dan rasio efisiensi staf

a. Rasio Biaya Operasional Pelayanan

Terhadap Partisipasi Bruto

Tabel. 17

Rasio Biaya Operasional Pelayanan Terhadap Partisipasi Bruto

\begin{tabular}{|c|c|c|c|}
\hline Tahun & $\begin{array}{l}\text { Biaya } \\
\text { Pelayanan }\end{array}$ & Partisipasi Bruto & Rasio \\
\hline 2017 & $\mathrm{Rp} \quad 1.074 .518 .435,61$ & $\operatorname{Rp} 2.276 .102 .438,02$ & $47,21 \%$ \\
\hline 2018 & $\mathrm{Rp} \quad 1.678 .171 .208,27$ & $\operatorname{Rp} 3.292 .158 .263 .98$ & $50,97 \%$ \\
\hline 2019 & $\begin{array}{ll}\mathrm{Rp} & 2.231 .440 .128,12\end{array}$ & Rp 4.081.171.041,06 & $54,68 \%$ \\
\hline
\end{tabular}

Dari hasil perhitungan di atas dapat dinyatakan bahwa rasio biaya operasional atas pelayanan BMT Nurul Islam terus mengalami kenaikan nilainya, akan tetapi meskipun terjadi kenaikan pada nilai rasio BMT Nurul Islam memiliki nilai rasio di bawah $68 \%$ sehingga dapat dinyatakan bahwa pada aspek ini BMT Nurul Islam Efisien.

b. Rasio Aktiva Tetap Terhadap Total Aset

Tabel.18

Perhitungan Rasio Tetap Terhadap Total Aset Tahun 2017 - 2019 


\begin{tabular}{clcll}
\hline Tahun & Aktiva Tetap & Total Aset & Rasio \\
\hline 2017 & $\mathrm{Rp}$ & $724.518 .435,61$ & $\mathrm{Rp} 8.216 .132 .418,12$ & $8,81 \%$ \\
2018 & $\mathrm{Rp}$ & $3.178 .171 .208,27$ & $\mathrm{Rp} \mathrm{21.292.151.263,98}$ & $14,93 \%$ \\
2019 & $\mathrm{Rp}$ & $3.631 .440 .128,12$ & $\mathrm{Rp} \mathrm{28.082.176.041,06}$ & $12,93 \%$ \\
\hline \multicolumn{5}{l}{ Sumber: Laporan Keuangan BMT Nurul Islam(Telah diolah) }
\end{tabular}

Terlihat pada tabel bahwa masih terjadi fluktuasi rasio, akan tetapi rasio tersebut tidak melebihi batas yang telah di tetapkan yaitu $25 \%$ sehingga dapat dinyatakan bahwa rasionya Baik.

c. Rasio Efisiensi Staff

Tabel.19

Perhitungan Efisiensi Staff Tahun 2017 2019

\begin{tabular}{ccccl}
\hline Tahun & \multicolumn{2}{l}{ Aktiva Tetap } & Total Aset & Rasio \\
\hline 2017 & Rp & $724.518 .435,61$ & Rp 8.216.132.418,12 & $8,81 \%$ \\
2018 & Rp & $3.178 .171 .208,27$ & Rp 21.292.151.263,98 & $14,93 \%$ \\
2019 & Rp & $3.631 .440 .128,12$ & Rp 28.082.176.041,06 & $12,93 \%$ \\
\hline \multicolumn{7}{l}{ Sumber: Laporan Keuangan BMT Nurul Islam(Telah diolah) }
\end{tabular}

Dari data diatas dapat dilihat bahwa Rasio efisiensi staf BMT Nurul Islam memilik nilai rasio yang fluktuatif terjadi penurunan dan kenaikan, meskipun demikian nilai rasio yang diperoleh dari perhitungan tersebut sangatlah tinggi jauh di atas nilai yang di tetapkan yaitu $100 \%$ ini menunjukan bahwa efisiensi BMT Nurul Islam Baik.

\section{Aspek Likuiditas}

\section{a. Cash Rasio}

Tabel.20

Perhitungan Cash Rasio Tahun 2017 2019

\begin{tabular}{cllll}
\hline Tahun & Kas + Bank & Kewajiban Lancar & Rasio \\
\hline 2017 & $\mathrm{Rp}$ & $3.724 .518 .435,18$ & $\mathrm{Rp} \mathrm{15.208.132.418,32}$ & $24,49 \%$ \\
2018 & $\mathrm{Rp}$ & $4.178 .171 .208,38$ & $\mathrm{Rp} \mathrm{21.270.151.263,64}$ & $19,64 \%$ \\
2019 & $\mathrm{Rp}$ & $5.631 .440 .128,82$ & $\mathrm{Rp} \mathrm{26.182.176.041,18}$ & $21,51 \%$ \\
\hline \multicolumn{5}{l}{ Sumber: Laporan Keuangan BMT Nurul Islam(Telah diolah) }
\end{tabular}

Dari perhitungan rasio kas diatas dapat di lihat bahwa nilai rasio kas BMT Nurul Islam terjadi fluktuasi, namun secara umum dapat dikatakan bahwa pada aspek ini BMT Nurul Islam dapat dikategorikan cukup likuid (21\%-25\%) . b. Rasio Pembiayaan Terhadap Dana Yang Diterima

Tabel. 21

Perhitungan Rasio Pembiayaan Terhadap Dana Yang Diterima Tahun 2017 - 2019

\begin{tabular}{|c|c|c|c|}
\hline Tahun & Aktiva Tetap & Total Aset & Rasio \\
\hline 2017 & $\begin{array}{ll}\operatorname{Rp} & 5.624 .818 .435,95\end{array}$ & Rp 9.206.138.418,42 & $61,10 \%$ \\
\hline 2018 & $\begin{array}{ll}R p & 6.178 .171 .208,56\end{array}$ & $\operatorname{Rp} 11.292 .151 .263,71$ & $54,71 \%$ \\
\hline 2019 & $\operatorname{Rp} \quad 8.631 .440 .128,42$ & $\operatorname{Rp} 18.082 .076 .041,80$ & $47,73 \%$ \\
\hline
\end{tabular}

Dari hasil perhitungan di atas dari tahun 2017-2019 terlihat bahwa hanya pada tahun 2018 BMT Nurul Islam dalam aspek ini likuid karena berada pada rentang rasio 51\%-75\% sedangkan pada tahun 2017 dan 2019 pada aspek ini dinyatakan kurang likuid.

\section{KESIMPULAN}

Berdasarkan hasil analisis penelitian yang telah dilakukan, terkait dengan masalah tingkat kesehatan lembaga keuangan mikro syariah BMT Nurul Islam tahun 2017-2019 dengan menggunakan pedoman penilaian tingkat kesehatan KJKS dan UJKS yang di keluarkan menteri koperasi No. 35.3/Per/M.KUKM/X/2007, maka dapat disimpulkan hal-hal sebagai berikut:

1. Hasil peniliaian tingkat kesehatan BMT Nurul Islam tiga tahun berturutturut pada periode 2017-2019 adalah sebagai berikut:

a. Pada tahun 2017-2019 penilaian yang dilakukan pada BMT Nurul Islam berdasarkan 35.3/Per/M.KUKM/X/2007 dengan aspek yang dinilai hanya 4 aspek, yaitu aspek permodalan, kualitas aktiva produktif, efisiensi dan likuiditas.

b. Analisa kesehatan BMT Nurul Islam dilakukan dengan pendekatan kuantitatif. 


\section{JQIM}

2. Secara umum dapat dinyatakan bahwa kesehatan lembaga keuangan mikro syariah BMT Nurul Islam Batam adalah dalam kondisi SEHAT.

3. Setelah menganalisis permasalahan tingkat kesehatan BMT Nurul Islam tahun 2017-2019, penulis memberikan beberapa rekomendasi: pertama agar ada peneliti yang melengkapi analisa kesehatan lembaga keuangan BMT Nurul Islam ini pada aspek manajemen, kemandirian dan pertumbuhan, jatidiri koperasi, serta kepatuhan prinsip syariah.dan kedua masyarakat kota Batam khususnya agar jangan ragu untuk berpartisipasi dengan bergabung menjadi anggota ataupun nasabah BMT Nurul Islam Batam.

\section{REFERENSI}

Ang, A., \& Piazzesi, M. (2003). A NoArbitrage Vector Autoregression of Term Structure Dynamics with Macroeconomic and Latent Variables. Journal of Monetary Economics, 50(4), 745-787.

Aliza, Karnia Nur. "Penilaian Kinerja Koperasi Berdasarkan Peraturan Menteri Negara Koperasi Dan Usaha Kecil Dan Menengah Republik Indonesia Nomor:14/Per/M.KUKM/XII/200 9 (Studi Kasus Unit Simpan Pinjam) Koperasi Wanita Serba Usaha "Setia Budi Wanita" Jawa Timur)", 2014

Broner, F. A., Lorenzoni, G., \& Schmukler, S. L. (2013). Why Do Emerging Economies Borrow Short Term? Journal of the European Economic Association, 11(suppl_1), 67-100.

Kasmir. Bank dan Lembaga Keuangan Lainnya. Jakarta: PT Raja Grafindo Persada, 2002
Mahmudah, "Penilaian Tingkat Kesehatan Bank Syariah (Studi Komparasi CAMELS dan RGEC pada BSM, BMI dan BRI Syariah)", 2013

Iqbal, M. (2015). Pengolahan Data Regresi Linear Berganda dengan EViews 8. Jakarta: Perbanas Institute.

Li, H., Wang, J., Wu, C., \& He, Y. (2009). Are Liquidity and Information Risks Priced in the Treasury Bond Market? The Journal of Finance, 64(1), 467503 